\title{
Business Models and Blockchain: What Can Change?
}

\author{
Modelos de Negócios e Blockchain: O Que Pode Mudar?
}

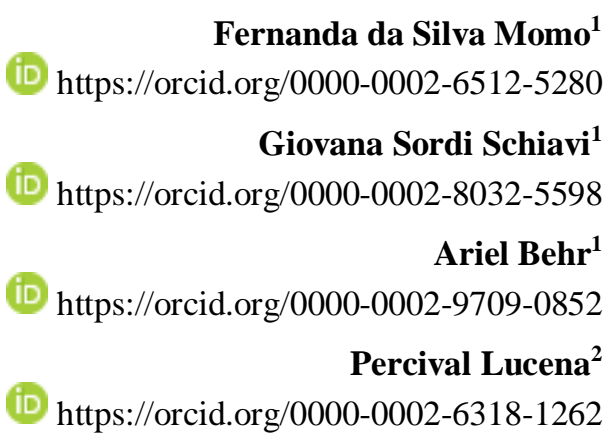

Universidade Federal do Rio Grande do Sul, Escola de Administração, Porto Alegre, RS, Brasil ${ }^{1}$ IBM Research, Porto Alegre, RS, Brasil ${ }^{2}$

Artigo recebido em 30.07.2018. Última versão recebida em 13.12.2018. Aprovado em 05.01.2019. 


\title{
Resumo
}

Este estudo objetivou identificar as características de modelos de negócios inovadores que utilizam a blockchain. Através de uma pesquisa qualitativa e descritiva, buscamos, no banco de dados Crunshbase, as empresas que tiveram em sua descrição de atividade o termo Blockchain, obtendo um total de 810 empresas. Os dados obtidos foram tabulados em planilha do Excel e realizou-se coleta de informações adicionais nos sites das organizações. O processo de análise de dados utilizou a técnica de análise documental e análise de conteúdo. Os resultados nos permitiram identificar que a maioria das organizações foi fundada a partir de 2014 e estão localizadas na América do Norte. Em relação à área de atuação das organizações, observa-se que a maioria delas atua na área Financeira e Tecnológica. Além disso, 10 empresas já estavam em funcionamento antes da criação da tecnologia blockchain, ressaltando a característica de uma tecnologia disruptiva que é a readequação de empresas estabelecidas. Por fim, destaca-se contribuições relacionadas ao campo, ao identificar as principais áreas de atuação dos negócios que utilizam a blockchain, bem como revelando descrições importantes sobre essas empresas. Além de contribuições para a teoria, ao apresentar evidências empíricas de negócios atuantes com essa tecnologia e suas contribuições para as diversas áreas de negócios.

Palavras-chave: modelos de negócio; blockchain; tecnologia disruptiva.

\begin{abstract}
The goal is to identify the characteristics of innovative business models that use blockchain technology. Through a qualitative and descriptive research, we sought, in the Crunshbase database, the companies that had in their activity description the word Blockchain, obtaining a total of 810 companies. The data obtained were tabulated in Excel spreadsheet and we carried out a collection of additional information on the websites of the organizations. The process of data analysis used the technique of document analysis and content analysis. The results allowed us to identify that most organizations' foundation date from 2014 and are located in North America. Regarding the area of expertise of these organizations, it can be observed that most of them belong to financial and technology areas. Moreover, 10 companies were already in operation before the creation of blockchain technology, pointing out the characteristic of a disruptive technology, which is the readjustment of established companies. Finally, we highlight the contributions related to the field, by identifying the main areas of business that use blockchain technology, as well as revealing important descriptions about these companies. In addition to contributions to the theory, by presenting empirical evidences of active business with this technology and its contributions to the various areas.
\end{abstract}

Keywords: business models; blockchain; disruptive technology.

JEL Code: O14, L16, O33. 


\section{Introduction}

Blockchain technology emerged as a solution for the elimination of the middleman in financial transactions (Nakamoto, 2008). Among its uses, the Bitcoin, a digital currency, stands out. However, it is important to note that this technology does not have the Bitcoin as its exclusive application. Conceptually it is possible to understand the blockchain as a database that has as its essential characteristics decentralization, security (encryption), reliability, automation, and publicity of information.

In this context, it appears that the blockchain has emerged as a "disruptive innovation with a wide range of applications, potentially able to redesign our interactions in business, politics and society at large" (Atzori, 2015, p. 1). Focusing on the business field, Cohen, Amorós and Lundy (2017) highlight that entrepreneurs are applying the blockchain technology to solve different problems in industries of various segments causing changes and transformation to the established models. However, it is not enough to just explore these disruptive technologies without the proper (re)structuring of business models to explore properly this technological and innovational potential (Hwang \& Christensen, 2008). Thus, Byrnes (2017, p. 1) points out that the companies that have the greatest strategic intelligence nowadays "are those which combine a high level of technology innovation with a business model that will help them make the most of it".

Every company that provides a particular service or product based on the relationship of trust between buyer and seller is vulnerable to the impact provided by blockchain in business, not only for market disruption, but also by offering new opportunities to create value in an appropriate business model to explore this technology (Cohen, Amorós, \& Lundy, 2017). Thereby, in view of the relevance of that subject to the current business context, this article seeks to answer the following research problem: What are the characteristics of the business models that use the blockchain? Considering the aspects presented in the question, this study aims to identify the characteristics of innovative business models that have adopted blockchain technology. To do so, the areas of expertise of these innovative models will be analyzed, as well as the general descriptions of these organizations will be presented.

For this purpose, by means of an essentially qualitative and descriptive research, we have queried Crunshbase for all companies listed in this repository that had, in their activity description, the word "blockchain". In this quest, a total of 815 firms were mapped for analysis, but only 810 firms have entered the search scope since 4 companies had already closed their activities and one company did not present data consistent with the search performed. In addition, to supplement this information, other documents of these companies were collected at their respective websites to help with this investigation. For the data analysis process, we used the document analysis technique and the content analysis technique to search for the answers to the problem raised in this study.

This research is structured as follows: the next section presents the background of the study, presenting aspects related to innovative business models in the literature, as well as explanations of the disruptive technologies and the blockchain. After that, we describes the methodological procedures used for this research, and, in the next section, the results obtained. Finally, in the last section, we presents the final considerations of this study.

\section{Background}

\section{Innovative business models}

The research on business strategies related to the structures of the business models have become significant around the 1990 with the advent of the internet (Fielt, 2014; Teece, 2010; Zott, Amit, \& Massa, 2011). That is because, in this period, the pressure from market globalization and the entry of new communication technologies spurred companies to rethink their business models (Kinder, 2002). This movement, consequently, accelerated the search for new forms of business structures, which allowed the passage of the existing business models for business models based on e-commerce, taking advantage of the opportunities, and thus arising in the market with the arrival of online age (Taran, Boer, \& Lindgren, 2015). 
In this sense, according to Simmons, Palmer and Truong (2013), the initial research characterized the business models as a strategy for restructuring the business practices in relation to environmental analysis. This fact reveals the importance of business models to evaluate the opportunities and threats that constantly arise on the market constantly, allowing to adjust the business structures according to these variables (Cohen \& Winn, 2007; Downing, 2005; Franke, Gruber, Harhoff, \& Henkel, 2008; George \& Bock, 2011; Sabatier, Mangematin, \& Rousselle, 2010; Sainio, 2004).

In this way, the business models are noticed as an integrated set of strategic, economic and operational elements that allows the creation of sustainable competitive advantage (Morris, Schindehutte, \& Allenc, 2005). Chesbrough (2007) and Teece (2010) argue that a business model describes the logic of creating and delivering value to customers, as well as the capture of value by an organization so that it achieves sustainable competitive advantages in the market in which it operates.

However, in the last two decades, studies on business models have intensified (Zott et al., 2011) and taken different directions (Taran, Nielsen, Montemari, Thonsen, \& Paolone, 2016), including working on innovation in business models, being the focus of study of many academics and managers (Chesbrough, 2010; Simmons, Palmer, \& Truong, 2013; Teece, 2010). This attention to the innovation of business models is a direct reaction to the increasing competitiveness and the constant changes in the market and consumer demands (Pereira, Imbrizi, Freitas, Alvarenga, 2015). This way, products, services, and processes with increasingly short life cycles contribute to innovations not only in relation to those elements, but also in relation to business models (Gassmann, Frankenberger, Csik, 2013; Pacheco, Klein, \& Righi, 2016).

On that basis, the revision of Taran, Nielsen, Montemari, Thonsen, and Paolone (2016) points out that the innovation of business models can be caused by a reaction to external changes, a process oriented by discoveries, of a continuous learning process of the organization and the environment, or an evolutive process. Although there are these different approaches as to the motivations for innovation in business models, it should be noted that the search for new business models considers, in all cases, the needs of the customers (Magretta, 2002), seeking new forms of value proposition through the reorganization of the business structures (Bashir, Yousaf, \& Verma, 2016). In this sense, there has been, in recent years, a success in the market expressed not by the introduction of new products or services individually, but rather by the innovation of business models (Taran et al., 2016).

This is confirmed, for example, with the presence of the Uberization phenomenon in the current market (Bashir et al., 2016). This term refers to the innovative business model released by the Uber company that has made an impact to the taxi industry - so far established - by proposing a personal transportation service with a differentiated value proposition to their customers and making intensive use of technologies. Such a term is used currently to represent other companies that are innovating in their business models in the most different areas, according to the proposal submitted by Uber. Thereby, the innovation of business models by the introduction of new technologies (especially disruptive technologies) is highlighted in the management field and in literature (Sainio, 2004), since business structures are altered by the presence of these emerging technologies, creating innovative models and pressing the existing models (Cavalcante, 2013), being this the focus of this research.

\section{Disruptive technologies}

The emergence of new technologies makes modifications and innovations opportune for products, services, and processes. So, while they create opportunities, they also create challenges for organizations. In this regard, we highlight the changes arising from the adoption of technologies which impact on business performance, and may generate competitive advantage (Hamel \& Prahalad, 1994; Hwang \& Christensen, 2008; Lui, Ngai, \& Lo, 2016).

However, it should be noted that the adoption of a new technology does not presuppose the creation of a market disturbance or a strategic relevance for the organizations (Bower \& Christensen, 1995); Therefore, not all emerging technology can be considered disruptive. On that account, it is important that the organizations are able to identify the disruption potential of a technology so they can prioritize investments in technologies that have a higher probability of impacting the market, and thus, achieve a competitive differential (Sainio, 2004).

Thereby, the disruptive impact on the market focuses mainly on the discontinuation of the normal course of the process and on the interruption of established performance trajectories (Christensen, 1997). In this direction, 
according to Danneels (2004, p. 249), the disruptive technology is understood as "a technology that changes the bases of competition by changing the performance metrics along which firms compete". This is because, initially, the term disruptive technology introduced by Bower and Christensen (1995) and Christensen (1997), was used to refer to a new lower-cost technology, a factor that attracts customers that are more price sensitive (Govindarajan \& Kopalle, 2006) as well as an inferior performance.

According to Christensen (1997), disruptive technologies have a lower performance, since they tend to fall short of the dominant technologies regarding certain traditional criteria that are most valued by customers. The disruptive technologies, although, have a higher performance and exceed the capacities of dominant technologies in other attributes that are more appealing to marginal customers (Christensen, 1997). These characteristics of disruptive technologies enable the expansion of new market niches and the attack on established products and services in their traditional markets, shifting the dominant technologies and companies in he conventional market (Christensen, 1997).

About this initial conceptualization of disruptive technologies, some authors reveal other theoretical positions. First, Danneels (2004) rejects the issue that not all disruptive technologies appear in low-end markets, allowing consumers' decisions not to be taken only by the matter of low cost, but also by other criteria, such as quality, for example. Another issue mentioned is in the fact that Christensen (1997) states that disruptive technologies are often associated with the replacement market leadership of the dominant company (Cheng, Huang, Ramlogan, \& Li, 2017). In contrast, Naumov (2013) reveals that the disruptive technology leads to various kinds of interruption that can be technological or about market, for example, an old technology can be replaced, but the market leadership may be preserved (Cheng et al., 2017).

Finally, another rebutted aspect is in the rejection of disruptive technologies by established companies (Obal, 2017). Christensen (1997) states that the historical operators are less inclined to adopt a disruptive technology, in the face of the inherent risks about the change from established technology to the emergent one. Thus, while new participants obtain new opportunities with disruptive technologies, traditional operators take more risks (Cheng et al., 2017). Sood and Tellis (2011) contradict such notes and reveal the historical operators, as well as the new starters, see business opportunities in disruptive technologies, often adopting them.

Despite these different understandings, the discussion of the concept of disruptive technology, to the market, it has a profound effect on the way in which it addresses the technological competition, leading to a reevaluation of the way companies approach to these technological threats and opportunities (Sainio, 2004). In this context, the role of disruptive technology can be noticed in the construction of new groups of products, services and processes, enabling the attainment of competitive advantage, since such technology causes changes in business structures, provides improvements to the performance of organizations, and brings a new value proposition to the market (Lui et al., 2016; Sainio, 2004).

\section{Blockchain}

Blockchain is a technology that, likely, according to Tapscott and Tapscott (2016, p. 1), "will have the greatest impact on the future of the world economy". In this regard, several authors focus on the potential of impact and revolution of this technology in world economy from the creation of changes in organizations and in the way business are made (McKendrick, 2017; Tapscott \& Tapscott, 2017). Thus, this technology has a disruptive potential for the existing business models in various economic sectors.

In relation to the emergence of blockchain, this occurred in 2008 with the publication of the report Bitcoin: Peer-to-Peer Electronic Cash System, published by the Cryptography Mailing List (Frechette, 2017). In this report, considering that the "Commerce on the Internet has come to rely almost exclusively on financial institutions serving as trusted third parties to process electronic payments", Nakamoto $(2008$, p. 1) highlighted as necessary the development of an "electronic payment system based on cryptographic proof instead of trust" to allow "any two willing parties to transact directly with each other without the need for a trusted third party". Therefore, the blockchain came up with the goal of developing a technology that allows the exclusion of the intermediary agent of financial transactions. 
Nakamoto, in his report, validated the Bitcoin as a virtual currency from a peer-to-peer distributed method which came to be characterized as blockchain (Nakamoto, 2008; Swan, 2015; Yermack, 2017). In this sense, it is worth noting that, even though the blockchain has emerged based on the Bitcoin algorithm, this "is not a definitional feature of the blockchain, but a mere application thereof" (Pilkington, 2016, p. 10). Regarding to this definition, blockchain is a "visible (albeit intangible) consequence of the actions taken by the users of a network" (Pilkington, 2016, p. 10).

In more detail, the blockchain can be understood as a distributed and shared database, based on encryption to ensure the authenticity of information that allowed "for the first time, unrelated people to reach a consensus on the occurrence of a particular transaction or event without the need for a controlling authority" (Wright \& De Filippi, 2015, p. 2). So, in blockchain, all transactions are recorded in a block that is visible to the network participants who review and validate this transaction that, when validated, is connected to its predecessor thus creating a chain of blocks (Swan, 2015).

The way of registration is provided by a distributed and transparent (Iansiti \& Lakhani, 2017; Tsai, Blower, $\mathrm{Zhu}, \& \mathrm{Yu}, 2016$ ) chain of hashes (type of security mechanism) of digital signatures (type of electronic signature that encrypts documents) (Lemieux, 2016). So, once validated and added to the chain of blocks in chronological order, the information may not be removed or altered from the database because of the cryptographic and technology construction of the blockchain (Nakamoto, 2008). The legitimacy of this technology is not only in the references to the previous block, but in all transactions (Tsai et al., 2016; Tschorsch \& Scheuermann, 2016).

Finally, since the blockchain technology is not restricted to Bitcoin, it is worth mentioning the potential use of this technology. In this sense, Swan (2015) proposes three categories of blockchain in view of the different types of existing activities or possibilities with the use of this technology. Figure 1 summarizes the three categories proposed by Swan (2015).
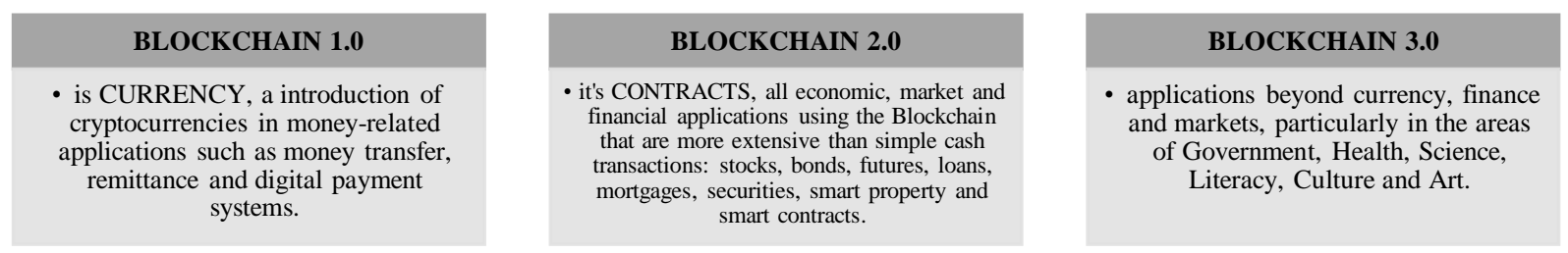

Figure 1. Categories of Blockchain

Source: Swan, M. (2015). Blockchain: Blueprint for a new economy. California: O'Reilly.

This categorization (Figure 1) identifies a strong possibility of the use of this technology in order to involve various fields of knowledge besides financial. Therefore, in view of this concept, characteristic and potential applications it is understandable why many consider it as the business internet. In addition, more directly, the decentralization stands out, according to Wright and De Filippi (2015), it can affect the way Governments, organizations, and society at large operate.

\section{Method}

Considering that in this research we seek to identify the characteristics of innovative business models using blockchain technology, a qualitative and descriptive research has been carried out, operationalized by documentary collection and analysis, besides content analysis. The data were collected from the Crunchbase database, an international repository created to have the main record of the most innovative companies in the world. It has business information about more than 100,000 global companies (not limited to startups) (Crunchbase, n.d.), and complemented with document collections on companies websites and on social networks like Linkedin.

On Crunchbase search field activity description, we searched for all companies that had the word blockchain. Therefore, companies that did not add the term blockchain in their description of activity in the Crunchbase were not included in this research, so there may be organizations (e.g., IBM, Microsoft) that work 
with this technology and are not included in the study in view of the search criteria used. In this quest, we have found a total of 815 companies that had their data extracted from Crunchbase, on October 21st, 2017, from a .csv file that was treated and transformed into an Excel spreadsheet. In this initial treatment of the database, in addition to adjustments in the rows and column tabs, 4 companies that had already closed their activities were excluded from the extracted data and a company that did not present data consistent with the search performed. So, we analyzed the data of 810 companies in this study. Regarding the data analysis process, it has been used documentary analysis techniques to work with the various documents collected and the analysis of content, with the aid of Nvivo 11 software, to categorize the organizations' areas of business as well as to perform cluster analysis and word frequencies.

We used the LSA (Latent Semantic Analysis) technique to define the analytical perspective for disruptive business models using blockchain technology. In order to that, we collected 19 articles that contained, in their titles or abstract, the term disruptive business model and were in the following databases: Capes / MEC Scientific Journals, EBSCO, SCOPUS and Web of Science. The discovery of a latent semantic structure hidden between the terms present in the documents (each article) that constitute a larger set of documents (19 articles) was possible with the LSA (Visinescu \& Evangelopoulos, 2014). Thus, the LSA technique highlighted the most relevant dimensions in the set of texts collected. Each dimension highlighted by the LSA is composed by a set of words and, to give meaning to these words in each dimension, we used content analysis, as indicated in the literature (Kulkarni, Apte, \& Evangelopoulos, 2014; Yu, Jannasch-Pennell, \& DiGangi, 2011). In this step, we have read the 19 articles in order to give meaning to the words in the dimensions. This process allowed us to identify the three perspectives of data analysis of this article in relation to disruptive business models.

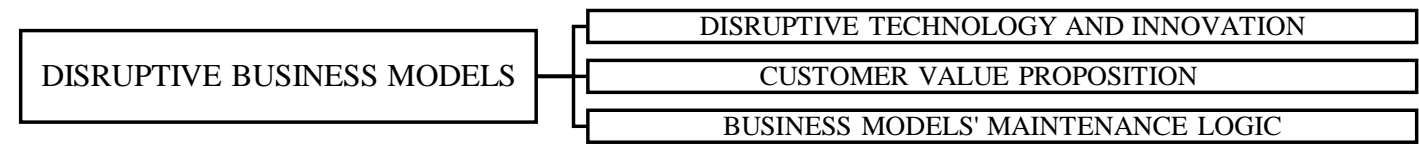

Figure 2. Analytical Perspective for Disruptive Business Models

The Disruptive Technologies and Innovation perspective is related to the way disruptive technology is used, in the case of this study, the blockchain. In other words, it seeks to understand how this technology is used in organizations and how it impacts on the business models of that organization. The Customer Value Proposition alludes to how the business changes the client's life from the product/service and how the technology is related to this value proposition. Finally, the Business Models' Maintenance Logic addresses how companies in the same segment are seeing that they need to pay attention to new technology that provides a business model disruption. In this perspective, one can assess the number of organizations in the same sector of activity and value proposition.

Finally, in order to improve the quality of the research, we have adopted different tests: Construct Validity, External Validity, Reliability and Credibility (Flick, 2009; Yin, 2015). For the Construct Validity, several sources of evidence - websites, social networks, e-mails - were used in the data collection to complement the information obtained in the Crunchbase. For the External Validity we carried out, in the data analysis, inferences related to the theory presented on the background. For Reliability, a statement was made with the research procedures in this section, in addition to the attention given to methodological rigor. Finally, in relation to Credibility, we validated the results of the research with two specialists in Information Systems.

\section{Results}

The first analyses allow to expose the characteristics concerning the database used in this study. In this sense, initially, we analyzed the number of companies founded by year highlighting in Figure 3, the chronology as well as the publication year of the article by Nakamoto (2008), which gave rise to blockchain technology. In relation to the results obtained in this analysis, it should be noted that most companies that mention blockchain technology in their description were founded from 2014 onwards. 
Furthermore, it was observed that 10 organizations listed in the database have been created by the year 2008. This fact deserves particular attention as it comes from companies that were already in operation and, from the emergence of a new technology, changed their business model in some way to use or offer products or services related to blockchain technology. Therefore, Figure 3 outlines a timeline about the companies created until 2008 and, then further analysis in relation to the business models of these organizations.
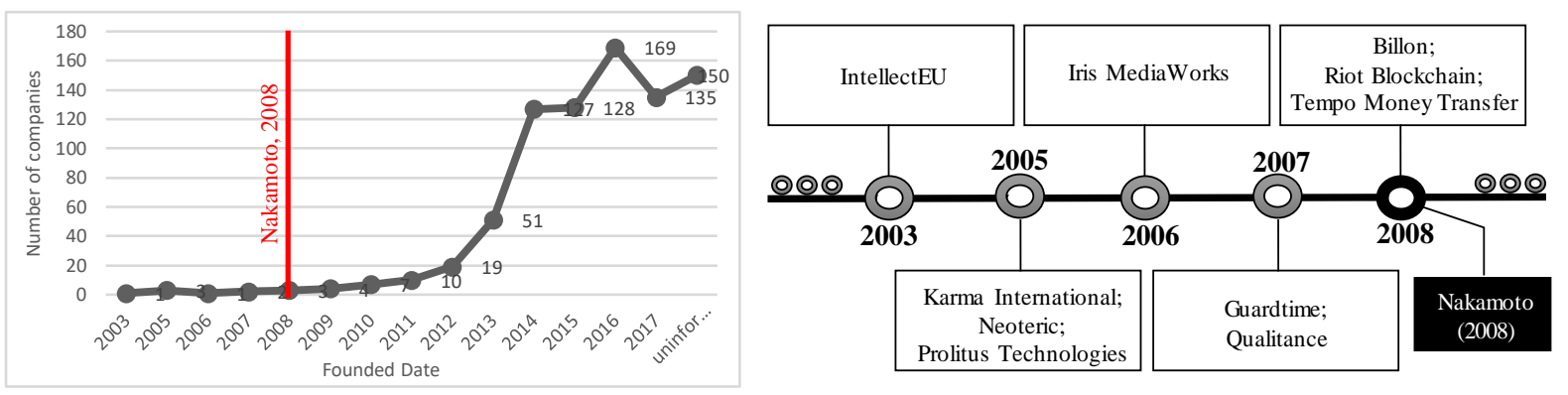

Figure 3. Number of Companies Founded by Year and Companies Until 2008

The IntellectEU is an international technology company, created in 2003, with "experience in financial integration, middleware and DLT development solutions" (Crunchbase-IntellectEU, n.d.). With intelligent integration and development as its motto, the IntellectEU has an extensive experience in "more than 150 integration projects implemented with various back-office systems, financial networks and ERPs" (IntellectEU, n.d.). As to the implementation of these projects, we point out the overall coverage of this organization that has projects in several countries in North America, Europe, Africa and the Middle East, and it has offices in New York, Brussels, Lisbon and Kiev (IntellectEU, n.d.).

The IntellectEU, as a technology company, declares as its challenges the "integration of financial messaging system; Integration of blockchain use cases; Make new FinTech applications work with legacy applications through the API structure" (IntellectEU, n.d.). In this sense, this organization offers services mainly for banks, fintechs, service bureaus, securities, vendors, corporations that are related, among other topics, to Swift, Blockchain, and Middleware (IntellectEU, n.d.).

Finally, we point out that this organization is a founding member of the Hyperledger of Linux Foundation, it has partnerships with IBM in order to implement blockchain technology. In addition, it is worth mentioning the IntellectEU acts specifically on the development of blockchain (DLT: Hyperledger, Ethereum, R3 Corda) and in integrating this technology with different platforms and applications (IntellectEU, n.d.).

Therefore, as to the features related to the business model of this organization, it is necessary to emphasize that, concerning the prospect of Disruptive Technology and Innovation, the above-mentioned organization uses blockchain as an end, since it is a technology company and is dedicated to the development of technological solutions to its customers. In addition, regarding the impact of the business model of this organization with the insertion of developments related to blockchain technology, there is the question of the competence development for structuring of applications that use this technology.

Regarding the Customer Value Proposition perspective, referring to the purpose of intelligent integration and development, IntellectEU seeks, on technological innovations like the blockchain, to bring innovation to its customers, always considering its high commitment to quality (IntellectEU, n.d.). Finally, with regard to the prospect of Business Models' Maintenance Logic, it should be noted the fact that IntellectEU had already been created before the advent of blockchain technology can signal that it is a company perceptive to possible disruptive technological innovations whereas it has integrated a technology like blockchain in its service before many other organizations in its sector and has a network with enterprises (e.g. IBM) and projects (e.g. Hypeledger) that are references in the development of blockchain technology.

Karma International is a media and entertainment business company which has been founded with the mission of "connecting exceptional, inspirational individuals socially and professionally through high profile experiential events, business networking, and social gatherings" (CrunchBase-KarmaInternational, n.d.). Over the last three years, the Karma "built an advanced membership technology platform to allow scalability in addition to 
the nine current activity venues in Los Angeles, Miami, Las Vegas, Orange County, San Diego, San Francisco, Houston, Bucharest and Kiev" (Crunchbase-KarmaInternational, n.d.).

This way, Karma uses blockchain technology in its platform with the intent of fulfilling its new mission that is the provision of "Karma Protocol and Karma International Tokyo (KIT) to capacitate the worldwide members-based communities" (Karma International, n.d.). These communities include: "physical members organizations (e.g. golf clubs); Virtual member organizations (e.g. former students of the university); Non-profit organizations that do not have the operational "backbone" (ERP, CRM, Analytics, etc.)" (Karma International, n.d.).

Thereby, concerning the characteristics related to the business model of this organization it is necessary to emphasize that, with regard to the prospect of Disruptive Technology and Innovation, the use of blockchain by this organization transpires as a means since it is a company in the business of media and entertainment using blockchain technology to structure the platform that will operationalize its actions and propitiating a boost in the scalability of its performance from the "decentralization era" (Karma International, n.d.). In this sense, the impact on the business model of this organization with the insertion of the blockchain technology is related to the expansion of the activities of this organization.

With reference to the Customer Value Proposition, it is worth mentioning that it is an ongoing project which also involves the support of customers and investors for its implementation. In addition, another highlight in this perspective is the feature of the organization to be based on the value being provided with the exchange between "exceptional and inspiring" (Crunchbase-KarmaInternational, n.d.) people. As regards the prospect of Logic and Maintenance of Business Models, it stands out the fact that the Karma International, even not being a company primarily in the technology business, is aware of new technologies that emerge and can change the form of business operation and thereby, when an opportunity glimpses, it is willing to change its business objectives.

The Neoteric operates in the IT industry and searches, as competitive differentiator, to "combine agile approach to projects with best practices of software engineering" (Crunchbase-Neorteric, n.d.) in order to better understand the needs of the business and thus carry out a software that brings profit to its customers (Neoteric, n.d.). Currently, the three main lines of action of Neoteric are the "start-up development; Outsourcing; API integrations" and has "great experience in creating startup projects for investors, implementing complex process automation solutions and working with blockchain technologies" (Crunchbase-Neoteric, n.d.).

Concerning the characteristics related to the business model of this organization it is necessary to emphasize that with regard to the prospect of Disruptive Technology and Innovation, the use of blockchain on this organization occurs as an end, namely in the production of software for its clients that use such a technology, but the blockchain is not presented as the main focus of applications development. Regarding the Customer Value Proposition is the major concern of this organization is to meet the expectations of its customers and help them achieve their business objectives (Neoteric, n.d.). Referring to the perspective of Logic and Maintenance of Business Models, it is the reason why this organization works with blockchain technology, that is, it is aware of the possible novelties related to its area of expertise. But it should be noted that the development related to this new technology is not currently presented as a main focus of Neoteric activity.

Prolitus Technologies is an IT company that seeks to innovate for "futuristic and sustainable Blockchain, AI, IoT based" (Crunchbase-ProlitusTechnologies, n.d.) solutions. Regarding its vision, it is worth mentioning that the Prolitus aims to help companies to "turn their ideas into meaningful products with a constant focus on the end-user experience and time to market, within a predictable budget" (Prolitus, n.d.). As regards the technological specialization, the constant search for update stands out, in addition to investments in "futuristic technologies like Blockchain, AI Machine Learning, IOT" (Prolitus, n.d.). It is worth mentioning that the main services offered by this organization are: Odoo/OpemERP; Blockchain Development; Internet of Things; AI \& Machine Learning; Application Security; Custom Software Development (Prolitus, n.d.). Another interesting point to be highlighted is that the Prolitus declares to accept Bitcoin as payment for its services (Prolitus, n.d.).

So, in respect of the features related to the business model of this organization, it is necessary to emphasize that, with regard to the prospect of Disruptive Technology and Innovation, the use of blockchain in this 
organization occurs primarily as an end in the development of technology to its customers that are using the blockchain. Moreover, it can be considered that, by allowing the payment of its services in bitcoin, there is a use of technology as a means to operationalize the business of Prolitus. In this sense, the impact on the business model of this organization with the insertion of the blockchain technology is related to the existence of prepared professionals prepared to develop applications with this technology and financial processes of the organization.

Concerning the Customer Value Proposition, it is worth mentioning that Prolitus has focused on the client organization and innovation, always seeking the development of "a not very technical software solution, but a solution that can solve real business problems and at the same time, that it is very simple to use" (Prolitus, n.d.). Finally, regarding the prospect of Logic and Maintenance of Business Models, it stands out that Prolitus demonstrates being concerned and aware of new technologies that can help in the development of solutions that meet the needs of its customers.

Iris Media Works is a company in the media and entertainment area that bills itself as a "digital consultancy and content creation collective that works with agencies and brands" (Crunchbase-IrisMediaWorks, n.d.). So, this organization harnesses the "power of emerging technology and award-winning content to create narratives that give clarity and purpose to the choices businesses and consumers make" (Crunchbase-IrisMediaWorks, n.d.). Therefore, Iris Media Works performs "from product demos and advertisements to branded content, live interactive shows and event coverage, in areas from fintech and blockchain apps to consumer goods and pharmaceuticals" (Crunchbase-IrisMediaWorks, n.d.).

On this account, about the characteristics regarding the business model of this organization, it is worth mentioning that, with respect to the prospect of Disruptive Technology and Innovation, the use of blockchain in this organization does not occur directly, since it points out that its services can assist in dissemination of solutions that use blockchain. That is, there is no impact on the business model of this organization. As regards the Customer Value Proposition, Iris Media Works is aware of the customer needs and explores business opportunities by inserting in its description the joint action with companies focused on innovation and using emerging technologies. With respect to the prospect of Logic and Maintenance of Business Models, the fact that this organization is aware of new technologies that emerge and market opportunitties related to these technologies stands out.

Guardtime is a team of cryptographers, developers and security architects, "with decades of experience defending networks from nation-state attack" (Guardtime, n.d.). Over the last decade, Guardtime team built "a technology platform called KSI that allows to tackle hard problems in security, supply chain, compliance and networking" and is based on blockchain technology (Guardtime, n.d.). In this sense, the company points out that the blockchain is only a "tool used to solve customer problems. Guardtime's mission in life is to leverage the tools we have built, work with partners and build the highest quality enterprise solutions" (Guardtime, n.d.). In this respect, as the company itself states, its "business model is to build long-term strategic partnerships with companies that are leaders in its field. We work together, leveraging our platform to build new solutions and take them to market" (Guardtime, n.d.).

So, regarding the prospect of Disruptive Technology and Innovation, the blockchain use in this organization takes place from the KSI platform and its applications and is, therefore, the main object within the Guardtime's business model. About the Customer Value Proposition, there is no doubt that the focus of this organization is not the provision of a software as product but a security solution to their customers. In this regard, the Guardtime stands out always for always being aware of the needs of its clients to best solve their problems. Finally, concerning the prospect of Logic and Maintenance of Business Models, it is worth pointing out the fact that this organization is aware of new technologies that can be of assistance to offer better solutions to its customers and partners.

Recognized as "one of the best technology companies of Europe", the Qualitance brings together a "robust innovation, along with the ability to build production-level technology" to the development of "revolutionary products and services that use next-generation technology" (Crunchbase-Qualitance, n.d.). In this way, Qualitance develops projects of innovation with its customers to design new products, services and business. In order to do that, Qualitance works in partnership with companies that seek disruptive innovations and positive impact in the world, as an example of partners (customers) we have: IBM; ING; IKEA (Qualitance, n.d.). Thereby, this 
organization works on the "development of products and services through software innovation, create for web, mobile and VR platforms that leverage the latest technologies (IoT, blockchain, machine learning) and help large companies execute big ideas at the speed of start-ups" (Qualitance, n.d.).

Regarding the characteristics relating to the business model of this organization it is necessary to emphasize that with respect to the prospect of Disruptive Technology and Innovation, the use of blockchain in this organization occurs as an end, more specifically on the development of software for its clients. In addition, Qualitance has as goal the use of disruptive technologies that can positively impact the world (Qualitance, n.d.). As regards Customer Value Proposition, it is the major concern of this organization not only to meet the expectations of its customers, but also to form a partnership with them in order for them to be aligned with the Qualitance values (disruption and positive impact) (Qualitance, n.d.). Finally, regarding the prospect of Logic and Maintenance of Business Models, the Qualitance's concern of the company with innovative technologies and use in its organizations stands out. Therefore, the aforementioned company is always striving to update the logic of its business model and its partner customers, all in an agile way.

Billon is a "complete solution in digital money on phones and computers" (Crunchbase-Billon, n.d.). Thereby, Billon users need no bank account or other banking service, like credit cards, inasmuch as the digital money can be used immediately by the users of a computer or smartphone (Crunchbase-Billon, n.d.). This is possible through the blockchain technology that "causes the digital money to be secure and trustworthy" (Crunchbase-Billon, n.d.). Billon, in its website, points out that its technology "supports all national currencies, is in compliance with the financial regulations and eliminates time and distance barriers" in order to be a technology that "takes care of people's needs in the digital age" (Billon, n.d.).

That being so, regarding the characteristics related to the business model of this organization, it is worth mentioning that with respect to the prospect of Disruptive Technology and Innovation, the use of blockchain in this organization occurs through solution/product offered by Billon, so it is a means to reach the business goals. That is, the business model of this organization relies on this technology. With regard to the Customer Value Proposition, Billon is aware of the people's needs in the digital era and proposes value with its solution in order to democratize the access to financial services, as well as making this services use more dynamic. With respect to the perspective of Logic and Maintenance of Business Models, it stands out the fact that this organization emerged from a preview of the potential use of blockchain technology, thus, it may be an indicator that its members are on the lookout for new arising technologies and market opportunity related to these technologies.

Riot Blockchain, "enjoys its expertise and its network to build and support blockchain technology companies" (Riot, n.d.). Thereby, this company has the intention, from an Advisory Council with technical experience, to "become a leading authority and supporter of blockchain, while providing investment exposure to the rapidly growing Bitcoin and blockchain ecosystems" (Riot, n.d.). Consequently, Riot has as an investment strategy "to identify unique projects, which decentralize markets; combining real-world applications with an active development team, strong fundamentals and large addressable markets” (Riot, n.d.).

So, regarding the characteristics related to the business model of this organization it is necessary to emphasize that the prospect of Disruptive Technology and Innovation, the use of blockchain in this organization does not occur directly considering that Riot operates as an investor in projects/companies that use this technology. But the impact of this technology is, currently, big in this organization since the focus of investments is only on organizations that use blockchain. As far as the Customer Value Proposition is concerned, there is not much exploration in relation to this topic, but the investments carried out by Riot seek to add financial value to its investors. Finally, regarding the prospect of Logic and Maintenance of Business Models, it should be emphasized the fact that this organization, even though wanting to focus on organizations that use the blockchain, could remain aware of new technologies that can represent new business opportunities.

Tempo Money Transfer is an organization focused on the transfer of money to countries that do not speak English (Crunchbase-TempoMoneyTransfer, n.d.). There is, in this organization, a concern to present the hybrid use "of the team expertise and the newest available technology to create the most convenient and reliable way for you to send money and digital assets to family and friends" (Tempo Money Transfer, n.d.). According to this organization what drives the changes in the existing business model of money transfer is the "use of the best technology, therefore, Time has specialized not only in the money transfer, but also in information technology". 
Furthermore, it states being "continually innovating and exploring new technology advances to make life easier for customers and members" (Tempo Money Transfer, n.d.). Thus, Tempo is currently using blockchain technology as an integration with the "financial platform, Stellar, which makes money transfers cheaper and easier" (Tempo Money Transfer, n.d.).

Therefore, in relation to the prospect of Disruptive Technology and Innovation, the use of blockchain in this organization happens from the Stellar platform integration and, thus, is a means-object within Tempo's business model. With respect to the Customer Value Proposition, it stands out the concern of the Organization to provide a safe and responsive service that, in the view of the Organization, is reached through the experience of its members and of the technology used. Finally, regarding the prospect of Logic and Maintenance of Business Models, this organization sees the use of technology as a differentiator in the transfer sector and, therefore, is aware of the possibility of using new technologies that arise and can improve its performance on the market.

In addition to analyzing the date of foundation of the organizations that constitute the database and the analysis of the organizations founded prior to 2008, we also identified the geographical position of these organizations. With respect to it, the 810 companies that make up the sample of this study are spread over 58 countries on 4 of the 5 continents. It is important to stress that it has not been possible to identify the origin of 263 organizations (uninformed). This information is more detailed in Figure 4.

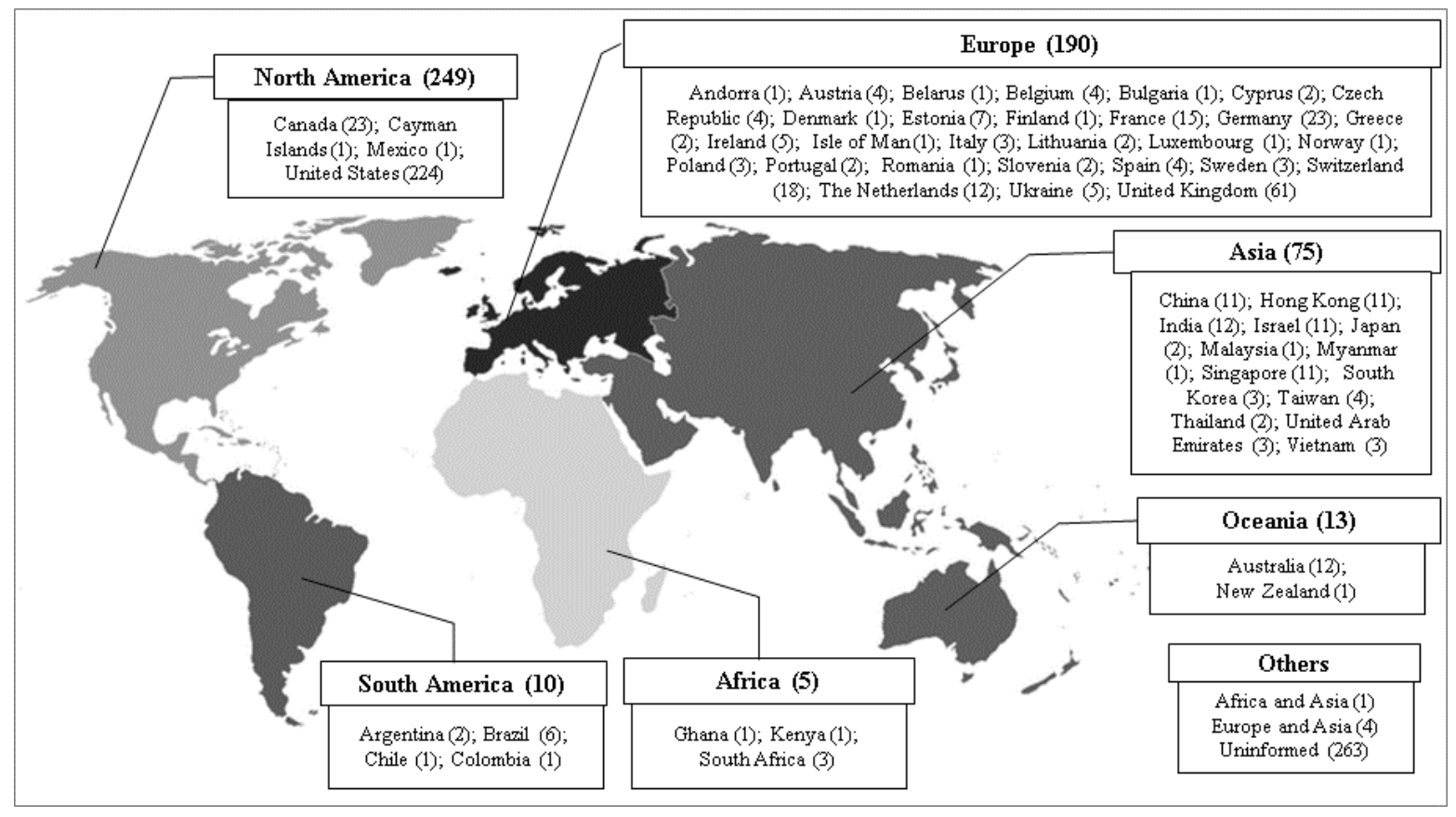

Figure 4. The Number of Companies By Country and Continent

It should be noted from Figure 4 that the northern hemisphere has a greater number of companies when compared with the southern hemisphere. Regarding the continents in which the organizations are located the organizations, the American continent comes out ahead in the quantity of companies, which is achieved by the large number of companies located in North America. So, after this continent, comes Europe (190 organizations), Asia (75), Oceania (13) and Africa (5). Finally, we highlight that the United States is the country with the largest concentration of companies (224 organizations).

In addition to knowing how the organizations are geographically distributed, we present next a brief analysis of the areas of activity of the companies in the analyzed database. Figure 5 presents the area of expertise of the organizations by continent as follows: 


\begin{tabular}{|c|c|}
\hline Africa & •Banking; Intelligent Systems; Real Estate; Payments \\
\hline Africa and Asia & •Publishing \\
\hline North America & $\begin{array}{l}\text {-Advertising; Agriculture; Apps; Artificial Intelligence; Association; Auto Insurance; Big Data; } \\
\text { Biotechnology; Bitcoin; Business Intelligence; Casino; Clean Energy; Clinical Trials; Cloud } \\
\text { Infrastructure; Compliance; Computer; Consulting; Consumer Lending; Credit Cards; } \\
\text { Crowdfunding; Cryptocurrency; Cyber Security; Data Integration; Data Mining; Data Storage; } \\
\text { Data Visualization; Developer APIs; Developer Tools; Digital Media; E-Commerce; Education; } \\
\text { Enterprise Applications; Enterprise Software; E-Signature; eSports; Events; Finance; Financial } \\
\text { Services; FinTech; Food and Beverage; Government; Hardware; Health Insurance; Identity } \\
\text { Management; Incubators; Information Services; Information Technology; Innovation } \\
\text { Management;Intellectual Property;Internet; Legal; Lending; Life Science; Linux; Loyalty } \\
\text { Programs; Machine Learning; Market Research; Media and Entertainment; Mobile; Music; } \\
\text { Network Hardware; Online Games; Operating Systems; Payments; PC Games; Peer to Peer; } \\
\text { Personal Health; Power Grid; Prediction Markets; Privacy; Product Design; Public Relations; } \\
\text { Real Estate; Retail Technology; SaaS; Search Engine; Security; Social Media; Social Network; } \\
\text { Software; Software Engineering; Sports; Sustainability; Trading Platform; Transaction } \\
\text { Processing; Transportation; Venture Capital; Video; Video Games; Virtual Currency; Wealth } \\
\text { Management }\end{array}$ \\
\hline South America & $\begin{array}{l}\text {-Bitcoin; Finance; Financial Exchanges; FinTech; Information Services; Internet; Mobile } \\
\text { Payments }\end{array}$ \\
\hline Asia & $\begin{array}{l}\text {-Android; Banking; Bitcoin; Cloud Storage; Computer; Cryptocurrency; Data Integration; } \\
\text { Document Management; E-Commerce; Education; Electronics; Enterprise Applications; } \\
\text { Enterprise Software; Environmental Engineering; Finance; Financial Exchanges; Financial } \\
\text { Services; FinTech; Fraud Detection; Health Care; Information Services; Information Technology, } \\
\text { Local Business; Market Research; Marketing; Network Hardware; News; Online Portals; } \\
\text { Payments; Recruiting; SaaS; Security; Skill Assessment; Social Network; Software; Trading } \\
\text { Platform; Transaction Processing }\end{array}$ \\
\hline Europe & $\begin{array}{l}\text {-Accounting; Apps; Architecture; Artificial Intelligence; Assisted Living; Assistive Technology; } \\
\text { Association; B2B; Banking; Big Data; Bitcoin; Business Development; Business Intelligence; } \\
\text { Cloud Computing; Cloud Storage; Collaborative Consumption; Compliance; Consulting; } \\
\text { Content; Crowdfunding; Cryptocurrency; Cyber Security; Data Storage; Database; Domain } \\
\text { Registrar; Energy; Energy Efficiency; Enterprise Software; Events; Finance; Financial } \\
\text { Exchanges; Financial Services; FinTech; Food Processing; Freelance; Gaming; GovTech; } \\
\text { Health Care; Humanitarian; Identity Management; Information Services; Information } \\
\text { Technology; Intellectual Property; Internet; Internet of Things; iOS; IT Management; Lending; } \\
\text { Logistics; Machine Learning; Marketing; Media and Entertainment; Mobile; Mobile Apps; } \\
\text { Mobile Payments; Music; Network Security; Parking; Payments; Personal Finance; Point of } \\
\text { Sale; Recruiting; Religion; Sales Automation; Security; Service Industry; Sharing Economy; } \\
\text { Social Network; Software; Software Engineering; Solar; Telecommunications; Trading } \\
\text { Platform; Training; Video Chat; Video Streaming; Web Apps; Web Design }\end{array}$ \\
\hline Europe and Asia & •Film Production; Finance; Internet; Software \\
\hline Oceania & $\begin{array}{l}\text {-AgTech; Augmented Reality; Big Data; Bitcoin; Human Resources; Independent Music; } \\
\text { Information Technology; Lending; Renewable Energy; Software }\end{array}$ \\
\hline
\end{tabular}

Figure 5. The Areas of Business Activity of the Companies By Continent

Considering the number of areas shown in Figure 5, we opted for a cluster analysis in order to identify which continents have more similarity in relation to the area of activity of the companies. Thus, Figure 6 allowed us to highlight 3 clusters, namely, three major groups of activities of the organizations in relation to their location. 


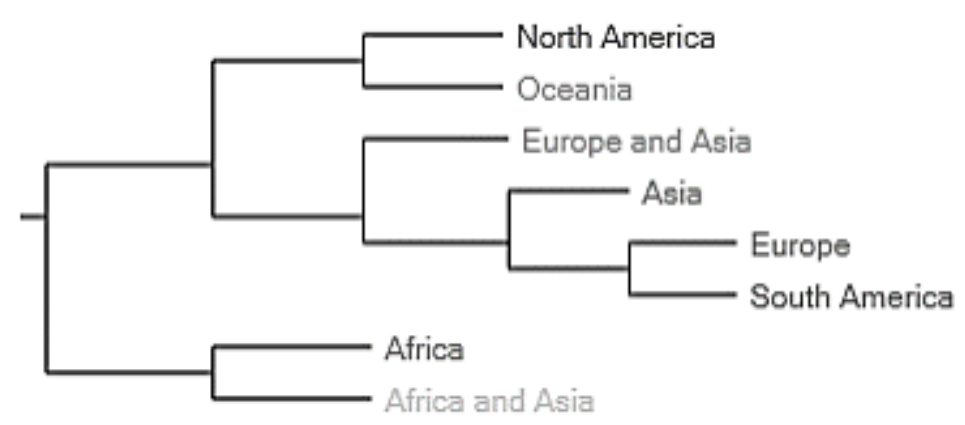

Figure 6. The Similarity of Areas of Activity of the Companies by Continent

In Figure 6 shows that area 1, with consists of North America and Oceania, has several branches of activity, but one can highlight, for example, the companies in the area of technology, finance, agriculture, media. Area 2 comprises Europe, Asia and South America, and stands out, for instance, in the operation of companies in the financial area, mobile payments, Exchanges and Information Services. Finally, area 3, which is essentially composed of Africa and Asia, has a more distant focus from area 1 and 2 which have many areas in common. The area has three performances in publications and financial services.

Even with this assembly related to the area of expertise of the organizations appearing in the database analyzed, we have observed that most of the companies are related to finance and technology. With regard to it, we present Figure 7 which features a word cloud about the areas of expertise of each organization and a word cloud about their descriptions.
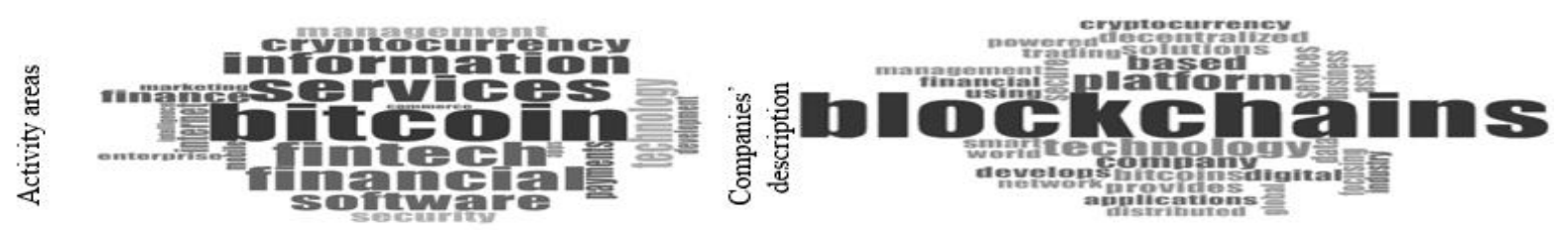

Figure 7. The trending words of the activity areas of the companies and the description of the companies

Figure 7 shows the large representation of the word bitcoin and how the financial sector can also be represented by this blockchain application. We shall point out that bitcoin can also be understood as a wellestablished and structured use of blockchain (Pilkington, 2016; Yermack, 2017), in such a way that since the publication of the Nakamoto (2008) there has been an emergence of technology and application. In addition, when observing the categories proposed by Swan (2015) it turns out that Blockchain 1.0 is still more prominent in relation to companies that operate in this segment.

Furthermore, it is possible to identify some economic applications of blockchain technology, which would be the 2.0 category described by Swan (2015). Finally, in relation to the Blockchain 3.0 category, - which, according to Swan (2015), involves applications beyond currency, financial area and markets - there is still an opportunity for the development and improvement of business models in this category of application that involves the governmental, health and arts areas. With regard to the area of expertise of those organizations, Figure 7 shows an analysis of descriptions of the companies.

This analysis reinforces the findings observed in the analysis of the areas of activity of the companies listed in the database and allows to identify a focus on the development of applications using the blockchain technology. That is to say, there are many technology companies where blockchain can be seen as an end product. In addition, it can be seen that, in their descriptions, organizations frequently mention blockchain characteristics, for example, decentralized or some applications like smart contract and cryptocurrency.

So, in this context of 810 companies, our next focus is in the area of business models of these companies. The following categorization is the outcome of the content analysis of the companies and their description 
available in the database. In addition to pointing out the areas of business models, we seek to categorize them as the uses described by Swan (2015).

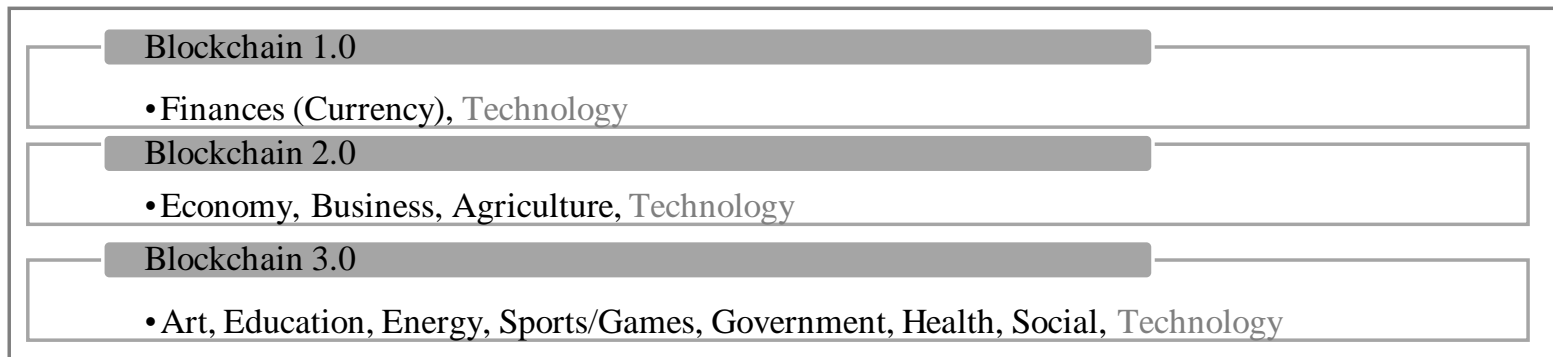

Figure 8. The Areas of the Business Models that Use the Blockchain

In relation to the Blockchain 1.0 category, we essentially highlight finance-related organizations which work mostly with bitcoin. We point out that the technology comes as a cross-sectional area in those categories proposed by Swan (2015), for technology organizations are companies specialized in developing software, platforms and, therefore, using blockchain, produce products for all categories. With respect to the characteristics of the business models of organizations from area 1, it stands out the intermediation of sale and purchase of cryptocurrencies, as well as offering wallets to store these assets.

Regarding Blockchain 2.0 category, there are many applications and services related to economy, business and agriculture. In the area of economy, we highlight the use of blockchain in smart contracts, promotion of collaborative consumption (and consequently the shared economy), collaborative funding (crowdfunding), credit services (credit card) and financial services in general (e.g. loans, payments), futures contracts (Hedge funds), trading platforms and applications related to the stock market. Moreover, there are venture capital (of investment), fintech and business incubator companies in this area.

Still on the Blockchain 2.0 category, we highlight that companies in thi area of business use of blockchain technology on subjects such as compliance, consulting, document management, domain registration, fraud detection, human resource management, intellectual property, marketing, logistics, recruitment, transactions processing, electronic signature, transportation (tracing). In this area is possible to notice that organizations are oriented to apply the blockchain technology to improve more administrative business processes, that is, using blockchain as a means in their business models. Finally, the use in agriculture is rather related to the uses in the Business area. There is a larger approach to use this technology on the improvement grain quality and food transport, and their origin tracking.

Finally, concerning Blockchain 3.0 category, it is worth mentioning, initially, this is a growing area that has a lower number of acting companies. In this regard, one can view this category as a prosperous environment for future growth. The areas in this category were arts, which mainly deals with the registration of copyright; Education, which offers courses related to blockchain; energy, which is related to electronics, energy efficiency, renewable energy, clean energy and solar energy. In addition to these areas aforementioned, there are the Sports/Games area, involving online games and sports; the Government, with the search for better data protection and providing services to population, control of expenses, prevention of corruption; Health, which involves clinical tests, diabetes, health care, science of life; and, finally, the application in the Social area that is related to NGOs, associations, social projects, sustainability, crowdfunding.

\section{Discussion}

The blockchain technology emerged in the last decade as a great promoter of disruptive innovations for business. That is because its wide possibility of applications has deeply changed business relations not only of the businesses, but of the consumers as well. Thus, the exploitation of this technology in business has led to adjustments in the market, either by the entry of companies operating with blockchain or by the restructuring of businesses that seek to exploit the opportunities with that technology. In this context, this study sought to identify 
the characteristics of innovative business models that use blockchain technology. Therefore, in order to achieve this purpose, we searched and analyzed the different areas of expertise of innovative business models, as well as presenting general descriptions of the organizations which use blockchain technology in their business structures.

Thereby, we sought, in the Crunchbase database, for all companies listed in this repository that had the word blockchain in its activity description. In general, from the 810 companies identified, it can be observed that a large number of them were founded from 2014 onward, after the year of creation of this technology, with emphasis on the apex of companies operating with the blockchain being between the years 2015 and 2016, which shows how much the business that uses this technology is emerging. Still, from those 810 companies listed, most are concentrated in North America, a region characterized by the encouragement and the use of technologies with a high level of business impact.

With regard to the area of expertise of the organizations in the database analyzed, it can observed that most of the companies are related to the use of blockchain in the financial area and technology. This becomes evident by the representation of the word bitcoin, revealing how the financial sector can also be represented by this application of the blockchain technology. In addition to these main areas of use of the blockchain, we identified other areas that are working with this technology, using the blockchain as an end product, which were classified according to the categories of Blockchain (1.0, 2.0 and 3.0) proposed by Swan (2015). In relation to Blockchain 1.0 category, we highlight, essentially, organizations related to the financial area, especially those which work with bitcoins. Alternatively, regarding Blockchain 2.0 category, there are many applications and services related to economy, business and agriculture. Finally, with regard to Blockchain 3.0 category we point out the applications in the arts, education, energy, sports/games, government, health and social.

In addition, a prominent factor when a disruptive technology arrives on the market is the readjustment of enterprises for the operation and use of this new emerging technology. In the case of blockchain, it was verified the existence of 10 companies that were already in operation before the creation of this technology, they sought to align their business to the blockchain technology, willing to use it in their organizational structures or to offer products and services related to this technology. On the importance of understanding how a company organizes its business model to explore an emerging technology that has a big impact on the market, these companies were analyzed under 3 major perspectives that characterize the way of structuring of business models: Technologies and Disruptive Innovation, Customer Value Proposition and Logic and Maintenance of Business Models.

Regarding the first perspective, which seeks to characterize the form of disruptive technology, we noticed most companies examined focus on the development of applications using the blockchain technology, that is, the blockchain technology in these companies can be seen as an end product. Only 3 companies use the blockchain as a means activity and 1 uses the blockchain as both means activity and as end product. On the second perspective, which relates to how the business meets the needs of the customer and solves their problems through the product/service offered, the use of blockchain technology, as a means or as an end, adds value in what the customer receives, especially in relation to issues such as security and confidence. Finally, the third perspective, which addresses how companies pay attention to new incoming technologies on the market, as well as on the impact of these emerging technologies in business models, we noticed companies are aligned to this innovative and enterprising behavior, adopting such conduct in their business.

Through these analyses, the present research contributes with the field by identifying the main areas of business that use blockchain, as well as revealing important descriptions about these companies. Such findings contribute to the characterization of these innovative business models related to blockchain, helping professionals and entrepreneurs to understand this new niche of expertise that comes with the blockchain. In addition, this review on companies operating with the blockchain contributes to the theory by presenting empirical evidence of active business with this technology and how this technology is contributing to the various business areas.

This research has contributed, from the characterization of the operation environment of organizations that use blockchain technology, to promote restructuring of business practices from the environmental analysis (Simmons et al., 2013). Regarding the limitations of research, we point out that the analyses presented here are limited to a timeframe related to the data collection and also to companies that were listed in a specific database, the Crunchbase. In addition, there were some information that were not available in the Crunchbase and we could 
not obtain them - even through the websites, social networks and e-mail - that ended up being classified as uninformed in the analyses.

Finally, the discussion of this subject shows the emergence of blockchain technology, both in the academic and professional fields, revealing the importance of research on this topic. Thus, we suggest searches related to Blockchain 3.0 category which, according to Swan (2015), involves applications beyond currency, and financial markets, showing an opportunity for the development and improvement of business models in the government, health, and art areas, currently emergent and relevant topics of discussion in society. Furthermore, before the recent appearance of businesses that work with blockchain, analyzing empirically the business structures impacted by the disruption of the blockchain, revealed important insights on the business management that use this technology. In addition, an in-depth analysis with members of companies that use the blockchain can be valuable to an understanding of the benefits and challenges that this technology brings in specific economic environments.

\section{References}

Atzori, M. (2015). Blockchain technology and decentralized governance: Is the state still necessary? New York: Social Science Research Network.

Bashir, M., Yousaf, A., \& Verma, R. (2016). Disruptive business model innovation: How a tech firm is changing the traditional taxi service industry. Indian Journal of Marketing, 46(4), 49-59. http://doi.org/10.17010/ijom/2016/v46/i4/90530

Billon. (n.d.). Our story. Retrieved August 12, 2017, from https://billongroup.com/about-us/

Bower, J. L., \& Christensen, C. M. (1995). Disruptive technologies: Catching the wave. Harvard Business Review.

Byrnes, N. (2017). The business issue. MIT Technology Review, 120(4), 2.

Cavalcante, S. A. (2013). Understanding the impact of technology on firms' business models. European Journal of Innovation Management, 16(3), 285-300. http://doi.org/10.1108/EJIM-10-2011-0085

Cheng, Y., Huang, L., Ramlogan, R., \& Li, X. (2017). Forecasting of potential impacts of disruptive technology in promising technological areas: Elaborating the Sirs epidemic model in Rfid technology. Technological Forecasting and Social Change, 117, 170-183. http://doi.org/10.1016/j.techfore.2016.12.003

Chesbrough, H. (2007). Business model innovation: It's not just about technology anymore. Strategy \& Leadership, 35(6), 12-17. https://doi.org/10.1108/10878570710833714

Chesbrough, H. (2010). Business model innovation: Opportunities and barriers. Long Range Planning, 43(2), 354363. http://doi.org/10.1016/j.lrp.2009.07.010

Christensen, C. M. (1997). The innovator's dilemma: When new technologies cause great firms to fail. Cambridge: Harvard Business Review Press.

Cohen, B., \& Winn, M. I. (2007). Business model innovation: Opportunities and barriers. Journal of Business Venturing, 22(1), 29-49. http://doi.org/10.1016/j.jbusvent.2004.12.001

Cohen, B., Amorós, J. E., \& Lundy, L. (2017). The generative potential of emerging technology to support startups and new ecosystems. Business Horizons, 60(6), 741-745. http://doi.org/10.1016/j.bushor.2017.06.004

Crunchbase. (n.d.). Our mission. Retrieved December 8, 2017, from https://about.crunchbase.com/about-us/

$\begin{array}{lllllll}\text { Crunchbase-Billon. } & \text { (n.d.). Billon group. Retrieved December 8, 2017, from }\end{array}$ https://www.crunchbase.com/organization/billon-group 
Crunchbase-IntellectEU. (n.d.). IntellectEU. Retrieved December 08, 2017, from https://www.crunchbase.com/organization/intellecteu

Crunchbase-IrisMediaWorks. (n.d.). IRIS mediaworks Ltda. Retrieved December 08, 2017, from https://www.crunchbase.com/organization/iris-mediaworks-ltd\#section-overview

Crunchbase-KarmaInternational. (n.d.). Karma International. Retrieved December 08, 2017, from https://www.crunchbase.com/organization/karma-international

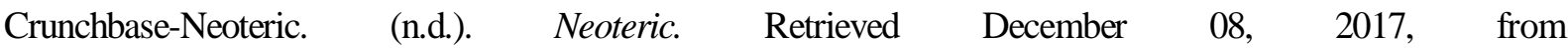
https://www.crunchbase.com/organization/neoteric

Crunchbase-ProlitusTechnologies. (n.d.). Prolitus Technologies. Retrieved December 08, 2017, from https://www.crunchbase.com/organization/prolitus-technologies

Crunchbase-Qualitance. (n.d.). Qualitance. Retrieved December 08, 2017, from https://www.crunchbase.com/organization/qualitance

Crunchbase-TempoMoneyTransfer. (n.d.). Tempo Money Transfer. Retrieved December 08, 2017, from https://www.crunchbase.com/organization/tempo-france

Danneels, E. (2004). Disruptive technology reconsidered: A critique and research agenda. Journal of Product Innovation Management, 21(4), 246-258. http://doi.org/10.1111/j.07376782.2004.00076.x

Downing, S. (2005). The social construction of entrepreneurship: Narrative and dramatic processes in the coproduction of organizations and identities. Entrepreneurship theory and Practice, 29(2), 185-204. http://doi.org/10.1111/j.15406520.2005.00076.x

Fielt, E. (2014). Conceptualising business models: Definitions, frameworks and classifications. Journal of Business Models, 1(1), 85-105. http://doi.org/10.5278/ojs.jbm.v1i1.706

Flick, U. (2009). Managing quality in qualitative research. London: Sage.

Franke, N., Gruber, M., Harhoff, D., \& Henkel, J. (2008). Venture capitalists' evaluations of start-up teams: tradeoffs, knock-out criteria, and the impact of VC experience. Entrepreneurship Theory and Practice, 32(3), 459-483. http://doi.org/10.1111/j.1540-6520.2008.00236.x

Frechette, J. (2017). Blockchain technology: Digitizing the global financial system. Retrieved Mach 3, 2018, from https://vc.bridgew.edu/honors_proj/193/

Gassmann, O., Frankenberger, K., \& Csik, M. (2013). The st. gallen business model navigator [Working Paper]. University of St. Gallen, St, Gallen, Suíça.

George, G., \& Bock, A. J. (2011). The business model in practice and its implications for entrepreneurship research. Entrepreneurship Theory and Practice, 35(1), 83-111. http://doi.org/10.2139/ssrn.1490251

Govindarajan, V., \& Kopalle, P. K. (2006). Disruptiveness of innovations: Measurement and an assessment of reliability and validity. Strategic Management Journal, 27(2), 189-199. http://doi.org/10.1002/smj.511

Guardtime. (n.d.). About Guardtime. Retrieved December 8, 2017, from https://guardtime.com/about

Hamel, G., \& Prahalad, C. K. (1994). Competing for the future. Boston: Harvard Business School Press.

Hwang, J., \& Christensen, C. M. (2008). Disruptive innovation in health care delivery: A framework for business model innovation. Health Affairs, 27(5), 1329-1335. http://doi.org/10.1377/hlthaff.27.5.1329

Iansiti, M., \& Lakhani, K. R. (2017). The truth about blockchain. Harvard Business Review, 91(1), 118-127.

IntellectEU. (n.d.). About IntellectEU. Retrieved December 8, 2017, from https://www.intellecteu.com/ 
Karma International. (n.d.). Karma international. Retrieved December 8, 2017, from https://www.karmainternational.com/

Kinder, T. (2002). Emerging e-commerce business models: An analysis of case studies from west lothian, scotland. European Journal of Innovation Management, 5(3), 130-151. https://doi.org/10.1108/14601060210436718

Kulkarni, S. S., Apte, U. M., \& Evangelopoulos, N. E. (2014). The use of latent semantic analysis in operations management research. Decision Sciences, 45(5), 971-994. https://doi.org/10.1111/deci.12095

Lemieux, V. L. (2016). Trusting records: Is blockchain technology the answer? Records Management Journal, 26(2), 110-139. https://doi.org/10.1108/RMJ-12-2015-0042

Lui, A. K., Ngai, E. W., \& Lo, C. K. (2016). Disruptive information technology innovations and the cost of equity capital: The moderating effect of CEO incentives and institutional pressures. Information Management, 53(3), 345-354. https://doi.org/10.1016/j.im.2015.09.009

Magretta, J. (2002). Why business models matter. Harvard Business Review, 80(5), 86-92.

McKendrick, J. (2017). Why blockchain may be your next supply chain. Retrieved from https://www.forbes.com/sites/joemckendrick/2017/04/21/why-blockchain-may-be-your-next-supplychain/683f435c13cf

Morris, M., Schindehutte, M., Allenc, J. (2005). The entrepreneur's business model: Toward a unified perspective. Journal of Business Research, 58(6), 726-735. https://doi.org/10.1016/j.jbusres.2003.11.001

Nakamoto, S. (2008). Bitcoin: A peer-to-peer electronic cash system. Retrieved from http://bitcoin.org/bitcoin.pdf.

Naumov, S. A. (2013). Case study of the competitive behavior of companies in response to disruptive technologies in the dynamic environment of changing user needs (Unpublished doctoral dissertation). Massachusetts Institute of Technology, United States.

Neoteric. (n.d.). Neoteric. Retrieved December 8, 2017, from https://neoteric.eu/

Obal, M. (2017). What drives post-adoption usage? Investigating the negative and positive antecedents of disruptive technology continuous adoption intentions. Industrial Marketing Management, 63, 42-52. https://doi.org/10.1016/j.indmarman.2017.01.003

Pacheco, F. B., Klein, A. Z., \& Righi, R. R. (2016). Modelos de negócio para produtos e serviços baseados em internet das coisas: Uma revisão da literatura e oportunidades de pesquisas futuras. Revista de Gestão, 23(1). http://doi.org/10.1016/j.rege.2015.12.001

Pereira, S., Imbrizi, F. G., Freitas, A. D. G., \& Alvarenga, M. A. (2015). Business model as an inducer of disruptive innovations: The case of Gol Airlines. International Journal of Innovation, 3(2), 28-42. http://doi.org/10.5585/iji.v2i2.24

Pilkington, M. (2016). Blockchain technology: Principles and appligations. In F. X. Olleros \& M. Zhegu (Eds.), Research handbook on digital transformations (pp. 225-253). Massachusetts: Edward Elgar Publishing.

Prolitus. (n.d.). About us. Retrieved December 8, 2017, from https://www.prolitus.com/about

$\begin{array}{llllll}\text { Qualitance. (n.d.). } & \text { Qualitance. } & \text { Retrieved } & \text { December } & \text { 8, 2017, from }\end{array}$ https://www.crunchbase.com/organization/qualitance

Riot. (n.d.). About Riot. Retrieved December 8, 2017, from https://ir.riotblockchain.com/

Sabatier, V., Mangematin, V., \& Rousselle, T. (2010). From recipe to dinner: Business model portfolios in the European biopharmaceutical industry. Long Range Planning, 43(2), 431447. http://doi.org/10.1016/j.lrp.2010.02.001 
Sainio, L. M. (2004). A framework for analyzing the effects of new, potentially disruptive technology on a business model case-Bluetooth. International Journal of Electronic Business, 2(3), 255-273. https://doi.org/10.1504/IJEB.2004.005141

Simmons, G., Palmer, M., \& Truong, Y. (2013). Inscribing value on business model innovations: Insights from industrial projects commercializing disruptive digital innovations. Industrial Marketing Management, 42(5), 744-754. http://doi.org/10.1016/j.indmarman.2013.05.010

Sood, A., \& Tellis, G. J. (2011). Demystifying disruption: A new model for understanding and predicting disruptive technologies. Marketing Science, 30(2), 195-388. https://doi.org/10.1287/mksc.1100.0617

Swan, M. (2015). Blockchain: Blueprint for a new economy. California: O’Reilly.

Tapscott, D., \& Tapscott, A. (2016). Blockchain revolution. New York: Penguin Random House LLC.

Tapscott, D., \& Tapscott, A. (2017). How blockchain will change organizations. MIT Sloan Management Review, $58(2), 10-13$.

Taran, Y., Boer, H., \& Lindgren, P. (2015). A business model innovation typology. Decision Sciences, 46(2), 301331. https://doi.org/10.1111/deci.12128

Taran, Y., Nielsen, C., Montemari, M., Thomsen, P., \& Paolone, F. (2016). Business model configurations: A five-v framework to map out potential innovation routes. European Journal of Innovation Management, 19(4), 492-527. https://doi.org/10.1108/EJIM-10-2015-0099

Teece, D. J. (2010). Business models, business strategy and innovation. Long Range Planning, 43(2), 172-194. http://doi.org/10.1016/j.lrp.2009.07.003

Tempo Money Transfer. (n.d.). Tempo story. Retrieved December 8, 2017, from https://www.tempo.eu.com/en/about-tempo

Tsai, W. T., Blower, R., Zhu, Y., Yu, L. (2016, March). A system view of financial blockchains. Proceedings of the IEEE Symposium on Service-oriented System Engineering, Oxford, UK, http://doi.org/10.1109/sose.2016.66

Tschorsch, F., \& Scheuermann, B. (2016). Bitcoin and beyond: A technical survey on decentralized digital currencies. IEEE Communications Surveys and Tutorials, 18(3), 2084-2123. http://doi.org/10.1109/COMST.2016.2535718

Visinescu, L. L., \& Evangelopoulos, N. (2014). Orthogonal rotations in latent semantic analysis: An empirical study. Decision Support Systems, 62, 131-143. http://doi.org/10.1016/j.dss.2014.03.010

Wright, A., \& De Filippi, P. (2015). Decentralized blockchain technology and the rise of lex cryptographia. SSRN Electronic Journal, 1-58. http://dx.doi.org/10.2139/ssrn.2580664

Yermack, D. (2017). Corporate governance and blockchains. Review of Finance, 21(1), 7-31. http://doi.org/10.1093/rof/rfw074

Yin, R. K. (2015). Estudo de caso: Planejamento e métodos (5a ed.). Porto Alegre: Bookman.

Yu, C. H., Jannasch-Pennell, A., \& DiGangi, S. (2011). Compatibility between text mining and qualitative research in the perspectives of grounded theory, content analysis, and reliability. The Qualitative Report, 16(3), 730-744.

Zott, C., Amit, R., \& Massa, L. (2011). The business model: Recent developments and future research. Journal of Management, 37(4), 1019-1042. http://doi.org/10.1177/0149206311406265 


\author{
Authors \\ Fernanda da Silva Momo \\ Rua Washington Luiz, 855, 90040-060, Porto Alegre, RS, Brasil \\ E-mail address: fernandamomo@yahoo.com.br \\ Giovana Sordi Schiavi \\ Rua Washington Luiz, 855, 90040-060, Porto Alegre, RS, Brasil \\ E-mail address: giovanaschiavi@hotmail.com \\ Ariel Behr \\ Rua Washington Luiz, 855, 90040-060, Porto Alegre, RS, Brasil \\ E-mail address: ariel.behr@ufrgs.br \\ Percival Lucena \\ Rua Tutoia, 1157, Vila Mariana, 04007900, São Paulo, SP, Brasil \\ E-mail address: plucena@br.ibm.com
}

\title{
Contributions
}

1st author: Writing of the theoretical basis, collection and analysis of data.

2nd author: Writing of theoretical basis and data analysis.

3rd author: Contributions on data presentation, review and contributions to article writing.

4th author: Review and contributions to article writing.

\section{Funding}

This study was financed in part by the Coordenação de Aperfeiçoamento de Pessoal de Nível Superior - Brasil (CAPES - Finance Code 001).

\section{Conflict of Interest}

The authors have stated that there is no conflict of interest.

\section{Plagiarism Check}

The RAC maintains the practice of submitting all documents approved for publication to the plagiarism check, using specific tools, e.g.: iThenticate. 